National Agriculture and Water Research Center,

Ministry of Agriculture and Water, Saudi Arabia.

\title{
SOME ASPECTS ON THE EPIZOOTIOLOGY OF RECENT FOOT AND MOUTH DISEASE OUTBREAKS IN DAIRY FARMS IN SAUDI ARABIA \\ (With 2 Tables)
}

\section{By \\ M. A. FARAG*; A. AL-SUKAYRAN; K.S. MAZLOUM and A.M.AL-BOKMY}

*: Dept. of Foot and Mouth Disease, Veterinary Serum and Vaccine Research Institute, Abbassia, Cairo - Egypt.

(Received at 17/10/1998)

بعض النواحى الوبائية عن الأوبئة الحديثة لمرضية السعودية الحمى القلاعية

منتار عامر فرج ، عباللة محد الصقيران ، كمال صابر مظلوم البقهى

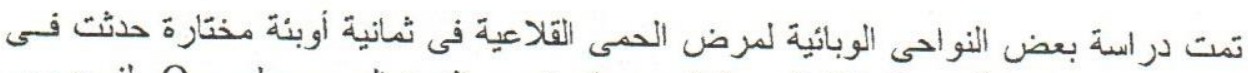

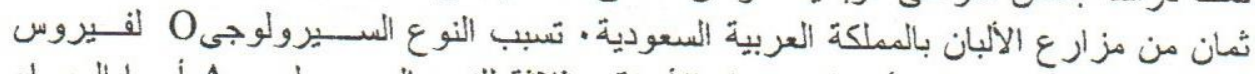

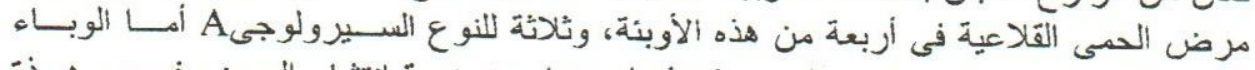

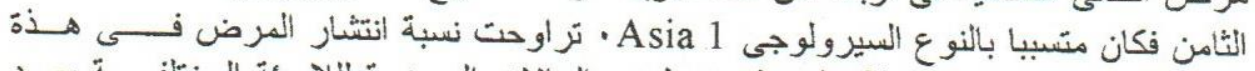

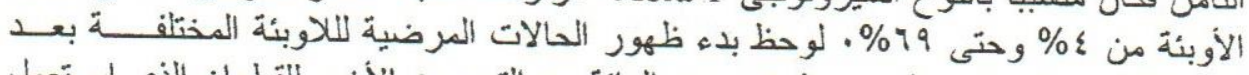

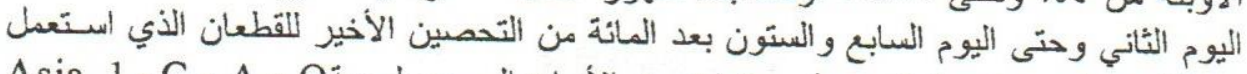

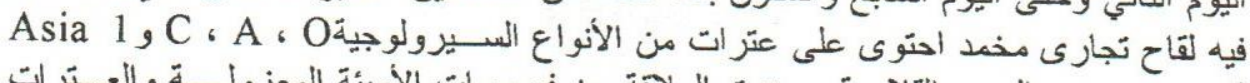

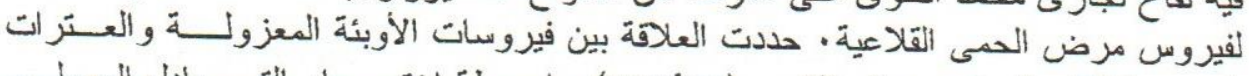

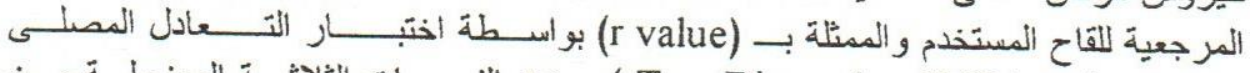

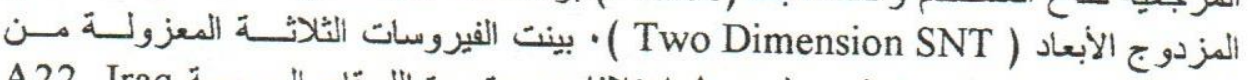

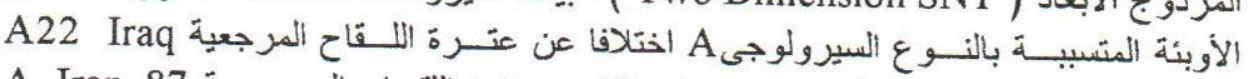

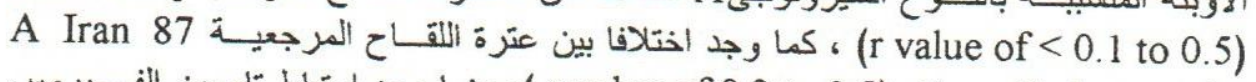

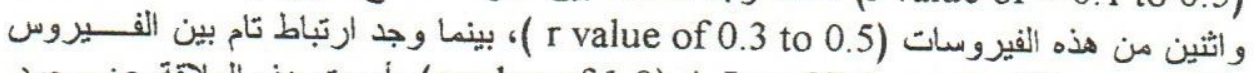

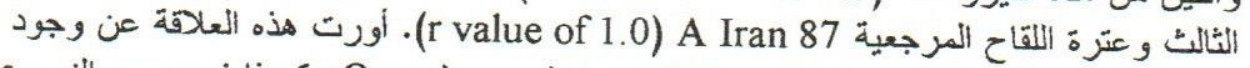

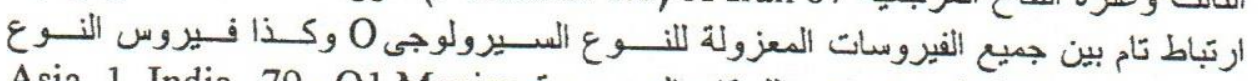

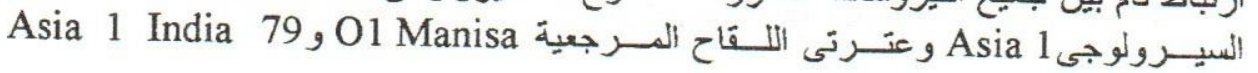




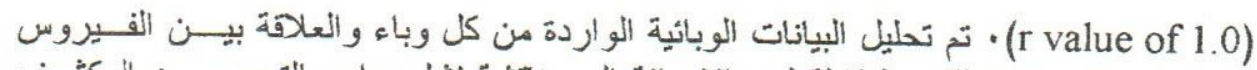

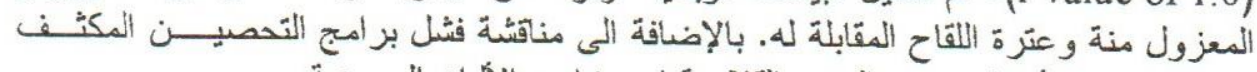

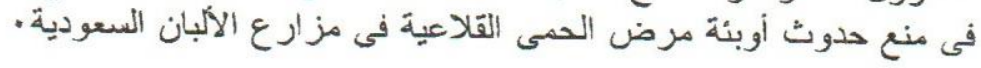

\section{SUMMARY}

Foot and Mouth Disease (FMD) outbreaks in eight separate dairy farms in Saudi Arabia from February 1992 to February 1998 have been studied. Four outbreaks were caused by serotype 0 , three with serotype $A$ and one with serotype Asia 1. The morbidity rates ranged from 4 to $69 \%$. Clinical cases were observed at between 2 and 167 days after the last herd vaccination using a quadrivalent commercial vaccine containing $\mathrm{O}, \mathrm{A}, \mathrm{C}$ and Asia 1 strains of FMD virus. The relationship between the vaccine strains and the viruses isolated during the outbreaks was assessed by the two dimensional neutralisation test and results expressed as $r$ values. The 3 viruses caused type A outbreaks showed antigenic variation as to compared to the reference vaccine strain $A 22 / \mathrm{Iraq}(\mathrm{r}=<0.1$ to 0.5 ). Of these, two viruses showed significant differences to A/Iran/87 ( $\mathrm{r}$ value of 0.34 to 0.4 ), but the third was strongly related ( $r$ value of 1.0 ). All type 0 and Asia 1 isolates showed closer antigenic relationship to the reference vaccine strains $\mathrm{O}_{1} / \mathrm{Manisa}$ and Asia $1 / \mathrm{India} / 79$. The epizootiological data of each outbreak and the relationship between the outbreak virus isolate and the relevant vaccine strain(s) are interpreted and the possible factors contributing to the recurrence of FMD outbreaks in Saudi dairy farms are discussed.

Keywords: Foot and Mouth Disease - Virus isolation - Typing - Antigenic variation - Epizootiology - Dairy farms - Saudi Arabia.

\section{INTRODUCTION}

Foot and Mouth Disease (FMD) is endemic in Saudi Arabia (AL- Mezaini et al., 1985, Hafez et al ., 1993 a, b, c, 1994 and Farag et al., 1998). The status of the disease in dairy farms in Saudi Arabia has been reported previously (Hafez et al., 1993 b). Since 1988, 28 outbreaks have occurred in 20 Saudi dairy farms. Eight outbreaks were selected for this study and the epizootiological data interpreted with the results of the relevant virological and serological investigations in an attempt to explain why intensive vaccination has failed to prevent outbreaks of FMD on dairy farms in Saudi Arabia. 


\section{MATERIALS and METHODS}

\section{Selection of the outbreaks:}

The outbreaks in this study were selected to reflect different situations in Saudi Arabia and thus elucidate factors contributing to the recurrence of FMD outbreaks in Saudi dairy farms. These selections also had results showing the relationship of the outbreak isolates with the reference vaccine strains.

\section{Epizootiological data}

The following data were collected after the occurrence of FMD outbreaks in each dairy farm, in collaboration with the concerned farms veterinarian(s),

The date of the last herd vaccination.

The current vaccination program.

The date of the appearance of the index case(s).

The daily progress of the disease.

The age of affected animals.

The number of animals in the farm and the number of each age group.

The duration of the outbreak.

\section{Samples for diagnosis:}

Vesicular fluids and epithelial tissues were collected from some freshly affected animals following the procedure described by Kitching and Donaldson (1987)

Virus isolation and typing:

Primary isolation of FMD virus was carried out on cell-culture monolayers of bovine kidney cells as previously described by Hafez et al., (1993 a). Viruses were typed using an ELISA kit provided by the FMD World Reference Laboratory (WRL- Pirbright, London, U. K.). The Indirect sandwich ELISA described by Roeder and LeBlanc Smith (1987), with slight modifications (Anon 1989), was used for serotyping isolates. To conduct serum neutralization test, all isolated viruses were adapted for growth in BHK 21 cells for 4-6 serial passages.

\section{Reference vaccine strains:}

The vaccine strains O1/Manisa, A22/Iraq/24/64 and Asia 1/India/79 were provided by the FMD-WRL, Pirbright, London, U.K. Serotype A/Iran/87 was provided by Rhone Merieux Limited, Ash Road, Pirbright, Woking, Surrey, London, U.K. 


\section{Antisera:}

Bovine antisera against O/Manisa, A22/Iraq, A/Iran/87 and Asia 1/India/79 were provided by Rhone Merieux Limited. These sera were obtained after homologous challenge of animals vaccinated with monovalent vaccines during potency testing.

\section{Determination of serological relationships}

The criteria establishing the antigenic relationship between vaccine strains and field virus strains, using $r$ values, was established by Rweyemamu et al., (1978) and Pereira (1978).

The $r$ value was calculated using the following equation (Pereira 1978):

$$
r=\frac{\text { titer of reference antiserum against field virus }}{\text { titer of reference antiserum against vaccine strain }}
$$

The interpretation of these criteria have been proposed and accepted by Samuel et al. (1990 a) as follows:

$r$ values of $0-0.19$. shows a highly significant variation, indicating a requirement for a vaccine strain with a closer relationship to the field virus.

$r$ values of $=0.2-0.39$. shows a significant difference to the reference strain, but protection may be satisfactory if a sufficiently potent vaccine is used.

$r$ values of $=0.4-1.0$. shows that strains are not significantly different.

\section{RESULTS}

\section{Epizootiological data 1992 -98 from eight outbreaks Outbreaks 1 to 4}

The outbreaks occurred in farms located in the Eastern and Central Regions of the Kingdom and were caused by serotype 0 viruses which were antigenically strongly related to the 01/Manisa vaccine strain (r value of 1.0). Outbreaks 1, 2 and 3 occurred during 1994 and 4 in January 1998. The morbidity rates were $24 \%$ (918 of 3812 ), $6 \%$ (152 of 2609 ), $28 \%$ (831 of 2999) and 26\% (510 of 2000) in farms 1, 2, 3 and 4 respectively (Table 1$)$.

\section{Outbreaks number 5, 6 and 7}

These outbreaks occurred in three different farms located in the Central Region and were caused by serotype A FMD viruses. Outbreaks 5 and 6 occurred in September 1992 and October 1993 and outbreak 7 occurred in February 1994. The morbidity rates were 38\% (707 of 1837), 
$4 \%(141$ of 3240$)$ and $69 \%$ (104 of 150) in farms 5, 6 and 7 respectively.

The $r$ value of the type A virus isolated from outbreak 5 showed that the virus was different to the vaccine strains $A 22 / \mathrm{Iraq}$ and $\mathrm{A} / \mathrm{Iran} / 87$ ( $\mathrm{r}$ values of 0.3 and 0.34 respectively). The isolate from outbreak $6 \mathrm{had} \mathrm{r}$ values of $<0.1$ with $\mathrm{A} 22 / \mathrm{Iraq}$ and 0.4 with $\mathrm{A} / \mathrm{Iran} / 87$. The isolate from outbreak 7 was closely related to A/Iran/87 ( $\mathrm{r}$ value 1.0 ) but was significantly different to A22/Iraq ( $\mathrm{r}$ value of 0.5 ) see Table 1.

\section{Outbreak number 8}

This was the single outbreak caused by serotype Asia 1 FMD virus in October 1993 in a farm in the Eastern Region. The morbidity rate was $30 \%$ (357 of 1172). The isolated virus is closely related to the vaccine strain Asia 1/ India /79 ( $\mathrm{r}$ value 1.0).

\section{Age groups of the affected animals in the eight outbreaks}

It was observed that a specific age group was mostly affected in outbreak 2 . In the other seven outbreaks, several (or all) age groups were affected. The data from these outbreaks are summarised in Table 2.

The numbers of suspected new cases, the duration of the outbreaks and the interval between last herd vaccination and the appearance of the index case(s) in each farm are shown in Tables 1 and 2 and Figures 1, 2 and 3.

\section{DISCUSSION}

The presence of an environment with enzootic Foot and Mouth Disease (FMD) puts the dairy farms at continuous risk from exposure to infection. Efforts are made to isolate farms by applying zoo-sanitary measures and through vaccination (Anon 1989 a, Hafez et al., 1993 b). Despite routine vaccination of dairy animals, FMD has recurred in some dairy farms (Hafez et al., 1986, Hafez, 1987, Hafez and Hussain 1988, Farag, et al., $1996 \&$ 1998). Three factors contribute to the recurrence of FMD outbreaks in Saudi dairy farms and these are:

a) The difficulty of getting a good herd immunity through immunization.

b) The variation of the FMD viruses and its transmissability.

c) The short duration of the immunity induced by the vaccines and it's sometimes poor quality.

Although outbreaks 1 to 4 were separated temporarily and geographically, the type 0 viruses isolated from the outbreaks were closely related to the vaccine strain O1/Manisa. The disease started in outbreak 1, in 172 heifers imported from USA, 5 days after their arrival at the farm and 3 days after primo-vaccination. The disease then spread 
to the rest of the original herd despite this having been vaccinated 2 months before. The outbreak was caused with a virus closely related to the vaccine strain O1/Manisa. The highly susceptible imported animals could amplify the infection to provide a high challenge to the vaccinated animals present in the original herd (Donaldson and Kitching 1989).

The animals in outbreak 2 were heifers collected from other dairy herds and their ages ranged from 4 to 24 months. The incidence of $77 \%$ clinically affected calves at 4-6 months of age could be the result of waning maternally derived antibodies (MDA), and also due to the lag period (at 4-6 months of age) between vaccination and the development of active immunity. Therefore, calves with waning MDA could become clinically infected with FMD virus before being able to response to FMD vaccination (Kitching and Salt 1995 and Farag et al., 1998).

The first clinical case of FMD in outbreak 3 was observed at 113 days post vaccination. In an unpublished local study made in a dairy herd located in AI-Kharj province, different age groups of animals were examined by SNT at 105 days post vaccination and $25 \%$ of the animals had antibody titers lower than the protective level $(<1: 45)$ (Kitching and Salt 1995). This indicates there is a need to evaluate the efficacy of the currently used FMD vaccine at 90,105 and 120 days post vaccination. Also there is a need to determine the optimal time at which herds should be re-vaccinated in highly endemic regions.

From the facts that the $4^{\text {th }}$ outbreak occurred at fifty days post vaccination, and the causative virus was closely related to the $\mathrm{O} 1 /$ Manisa vaccine strain, it is difficult to correlate the occurrence of the outbreak and the quality of the vaccine used. Nevertheless, re-vaccination of the herd with a good quality vaccine a few days after the first reported case could have helped in halting or slowing the spread of infection (Pay, 1984).

Regarding to type A outbreaks, the present study revealed a relation between the morbidity rate and the degree of antigenic variation of the isolated viruses as compared to the reference vaccine strains (Woolhouse et al., 1996). This relation is clear in outbreaks 5 and 6, whereas the morbidity rates were of $36 \%$ in unrelated virus of outbreak 5 and $4 \%$ in related virus of the outbreak 6 .

The application of a vaccination regime at 3,6 and 9 months of age (outbreak 7) appeared to increase the susceptibility of calves to infection. This could have been due to the depletion of MDA by the antigen of the vaccine (Kitching and Salt 1995, Farag et al., 1998). This 
explains why the highest morbidity rate $(69 \%)$ was recorded in this outbreak.

Inactivated vaccine gives protection for not more than 4 months (WRL of FMD, R.P. Kitching personal communication). Therefore, the application of unevaluated vaccination regimen that was made in farm 8 (herd vaccination at 6 months intervals) could have increased the number of susceptible animals at the beginning of the outbreak.

\section{CONCLUSIONS}

\section{It can be concluded that:}

1. The severity of an outbreak depends on the following;

a) The number of susceptible animals that are present at the beginning of the outbreak.

b) The antigenic variation of the outbreak virus compared to the vaccine strain(s).

c) The vaccination regimen used as well as the quality of the vaccine.

d) The interval between the date of the last vaccination and the first case reported.

It was observed that not only possibly partially immune animals were responsible for the spread of infection in these outbreaks, since immunized animals may not show clinical disease and may be capable of transmitting the infection to contact animals (Donaldson \& Kitching 1989).

2. Continuous monitoring of the relationship between the vaccine and field viruses is necessary to determine the suitability of the vaccine strains to possibly provide highest antigenic similarity and induce maximal protection against existing field viruses (Kitching et al.,

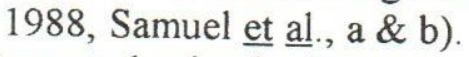

3. Imported animals should be vaccinated twice at the time of arrival and at 21 days intervals in quarantine before being allowed to mix with the herd.

4. The complete isolation of calves at 4-6 months of age is the only way to protect animals from infection (Kitching \& Salt 1995, Farag et al., 1998).

5. There is a need to evaluate the potency of the currently used FMD vaccines at 90,105 and 120 days post vaccination. Also there is a need to determine the time at which herd could be re-vaccinated in highly endemic regions. 
6. All the imported batches of the commercial FMD vaccines should be locally tested for their potency for each of the incorporated vaccine strains. This could possibly be made through examination of antisera post vaccination using a competitive ELISA using the antigens incorporporated in the vaccines.

7. Application of a vaccination regimen at 3,6 and 9 months of age increased the susceptibility of calves to infection (Kitching and Salt 1995 ) and should be avoided.

8. Herd vaccination at 4 months interval is the most reliable vaccination regimen.

9. Vaccination of calves should be made at 4- 6 months of age (Kitching and Salt 1995, Farag et al., 1998).

10. A nationwide vaccination campaign should be implemented.

11. A good quality vaccine should be manufactured locally.

\section{REFERENCES}

AL-Mezaini, S., Sinousi, Y., Chang, S.H., Hawari, A and Hafez, S. M. (1985): Some epizootiological aspects of Foot and Mouth Disease in Saudi Arabia. proc.Saudi Biol.Soc., 8: 267-279.

Anon (1989 a): "Foot and Mouth Disease policy". Masstock dairy Farms, Riyadh. 9 pp.

Anon (1989): Foot and Mouth Disease virus antigen detection : ELISA manual. Foot and Mouth Disease - World Reference Laboratory working protocol. $12 \mathrm{pp}$.

Donaldson, A. I. and Kitching, R. P. (1989): " Transmission of Foot and Mouth Disease by vaccinated cattle following natural challenge". Res. Vet. Sci. 46, 9-14.

Farag, M. A., AL-Sukayran, A.M., Mazloum, K.S. and AL-Bokmy, A.M. (1998): The efficacy of two Foot and Mouth vaccination regimens for calves of immunized dams in Saudi dairy farms. Assiut Vet. Medical Journal, 38: 76, 40-55.

Farag, M. A., Salt, J., Kitching, R. P., Pearson, A., AL-Bokmy, A.and Hafez, S.M. (1996): Preliminary studies on the carrier status among heifers raised in a Saudi dairy farm affected with successive outbreaks caused by serotypes $\mathrm{A}$ and $\mathrm{O}$ of Foot and Mouth Disease virus. In program and abstracts: 17th Annual Meeting of the Saudi Biological Sociiety, Buraidah, May, 1996, p. 83 . 
Hafez, S.M. (1987): "The epizootiology of Foot and Mouth Disease in dairy farms in Saudi Arabia". Proceeding of the workshop on Dairy production and Processing in Saudi Arabia. Ryiadh, April 1987, 185-198.

Hafez, S.M. and Hussain, H. I. (1988): "Factors contributing to the recurrence of Foot and Mouth Disease in dairy farms in Saudi Arabia". Programme and Abstracts: International Conference on the impact of Viral Disease on Health Care and Medical Services in Saudi Arabia and the Middle East. Riyadh, P. 170.

Hafez, S.M., Farag, M. A., Mazloum, K.S. and AL-Bokmy, A.M. (1993a): Application of double sandwich enzyme linked immunosorbent assay for the diagnosis of Foot and Mouth Disease in Saudi Arabia. Dtsch, Tierarztl. wschr. 100. 103 -106.

Hafez, S.M., Farag, M. A., Mazloum, K.S. and AL-Bokmy, A.M. (1994): "Serological survey of Foot and Mouth Disease in Saudi Arabia" Rev. Sci. Off. Int. Epiz. 13, 711-719.

Hafez, S.M., Farag, M. A. and AL-Sukayran, A. M. (1993 b): "Epizootiology of Foot and Mouth Disease in Saudi Arabia:II." Current status on dairy farms and control measures in operation". Rev. Sci. Off. Int. Epiz. 12,817.

Hafez, S.M., Farag, M., AL-Sukayran, A. M. and AL-Mujalli, D. M. (1993 c): "Epizoo-tiology of Foot and Mouth Disease in Saudi Arabia: I. analysis of data obtained through district field veterinarians". Rev. Sci. Off. Int. Epiz. 12, 807-816.

Hafe, S.M., MacKendrick, M.D., Barakat, A., Grymer, J., AL-Sukayran, A.M and AL-Mukayel, A. (1986): " recent epizootics of some dairy farms in Al- Kharj Region". Program and Abstracts: 9th Annual Meeting of the Saudi Biological Society, Riyadh, p.87.

Kitching, R.P. and Donaldson, A (1987): "Collection and transportation of specimens for vesicular virus investigations". Rev. sci. tech. Off. int. Epiz. 6, 263-272.

Kitching, R.P. and Salt, J. S. (1995): The interference by maternally derived antibody with active immunization of farm animals against Foot and Mouth Disease. Br. Vet.J.151,379-389.

Kitching, R.P., Rendle, R. and Ferris, N.P. (1988): "Rapid correlation between field isolates and vaccine strains of Foot and Mouth Disease virus". Vaccine 6, 403-408. 
Pay T.F. (1984): "Factors influencing the performance of Foot and Mouth Disease vaccines under field conditions". In: Applied Virology, Editors: E. Kurstak, W. El-Nakib and C. Kurstak, Academic press, 73-86.

Pereira, H.G. (1978): Antigenic variation in relation to epidemiology and control of Foot and Mouth Disease. Br. vet. j., 134, 58.

Roeder, P. L. and Le Blanc Smith, P.M. (1987): Detection and typing of Foot and Mouth Disease virus by enzyme linked immunosorbent assay: a sensitive, rapid and reliable technique for primay diagnosis. Res. Vet. Sci. 43,225-232

Rweyemamu, M.M., Booth, J.C., Head, M. and Pay, T.W.F. (1978): Microneutralization tests for serological typing and subtyping of Foot and Mouth Disease virus strains. J. Hyg., Camb., 81, $107-123$.

Samuel, A.R., Knoweles, N.J. and Kitching, R.P. (1990 b): "preliminary antigenic and molecular analysis of strains of Foot and Mouth Disease virus serotype O isolated from Saudi Arabia in 1988 and 1989". Report of the Session of the Reaserch Group of the standing Technical committee of the European commission for the control of Foot and Mouth Disease, Lindholm, Denmark. 139-145

Samuel, A.R., Ouldridge, E.J., Arrowsmith, A.E.M., Kitching, R.P and Knoweles, N.J. (1990 a): Antigenic analysis of serotype O Foot and Mouth Disease virus isolates from the Middle East, 1981 to 1988. Vaccine, 8, 390-396.

Woolhouse, M.E. J., Haydon, D. T., Pearson, A.and Kitching, R.P. (1996): Failure of vaccination to prevent outbreaks of Foot and Mouth Disease. Epidemiology and infection. 116: 3, 363-371. 


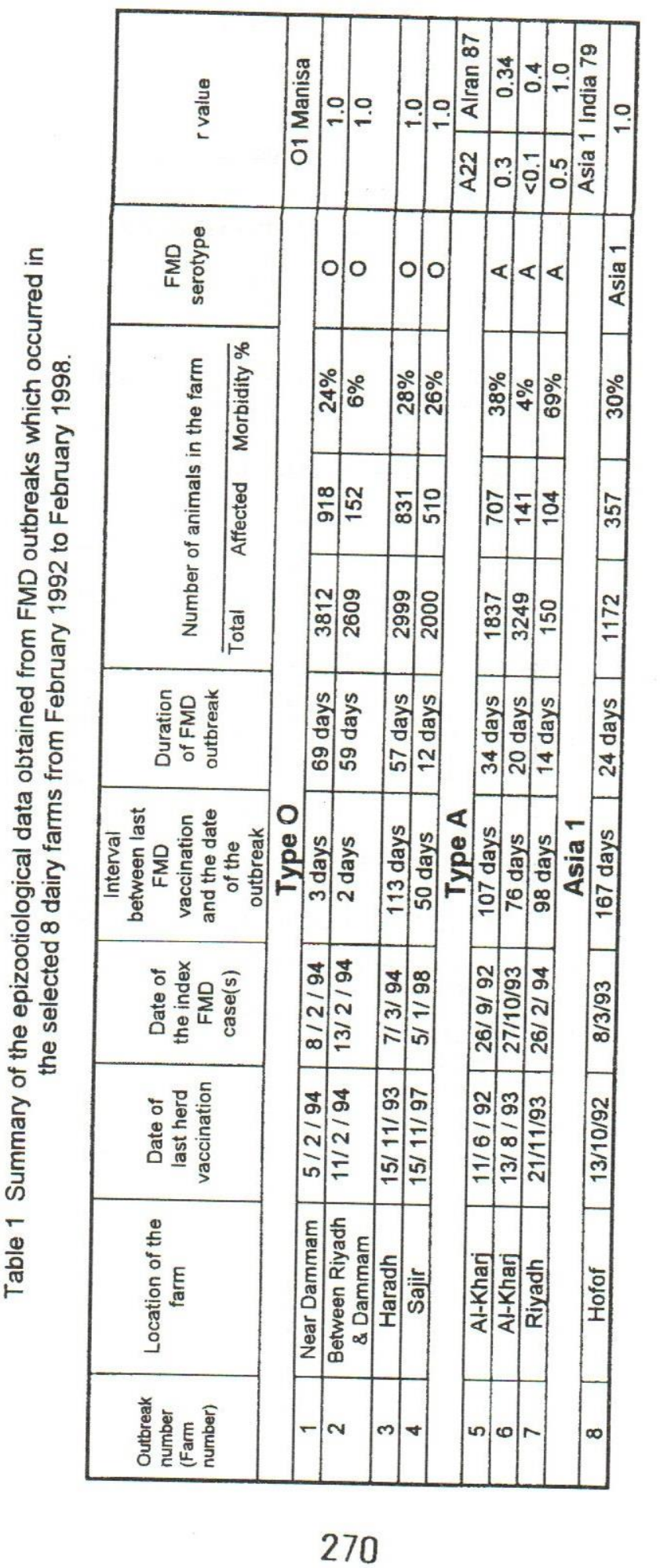


Table 2. Occurrance of FMD among different age groups of dairy animals during the period of outbreaks in the selected 8 dairy farms

\begin{tabular}{|c|c|c|c|c|c|c|c|c|c|c|}
\hline \multirow{3}{*}{\multicolumn{2}{|c|}{$\begin{array}{c}\text { outbreak } \\
\text { number } \\
\text { (Farm } \\
\text { number) }\end{array}$}} & \multicolumn{9}{|c|}{ Different age group of animals in the farm } \\
\hline & & \multicolumn{5}{|c|}{ Young stock } & \multicolumn{3}{|c|}{ Cows } & \multirow{2}{*}{$\begin{array}{c}\text { Grand } \\
\text { total }\end{array}$} \\
\hline & & $0-3 \mathrm{M}$ & $46 M$ & $7-16 M$ & $17-24 M$ & sub Total & L. . C & $\mathrm{D} \& \mathrm{ICH}$ & sub total & \\
\hline 1 & $\begin{array}{l}\mathrm{P} \\
\mathrm{A} \\
\% \\
\end{array}$ & $\begin{array}{r}420 \\
115 \\
27 \% \\
\end{array}$ & $\begin{array}{l}356 \\
213 \\
60 \% \\
\end{array}$ & $\begin{array}{r}544 \\
102 \\
19 \% \\
\end{array}$ & $\begin{array}{c}650 \\
77 \\
12 \% \\
\end{array}$ & $\begin{array}{c}1970 \\
507 \\
26 \% \\
\end{array}$ & $\begin{array}{c}1670 \\
239 \\
14 \% \\
\end{array}$ & $\begin{array}{c}172^{*} \\
172 \\
100 \% \\
\end{array}$ & $\begin{array}{c}1842 \\
411 \\
22 \% \\
\end{array}$ & $\begin{array}{r}3812 \\
918 \\
24 \% \\
\end{array}$ \\
\hline 2 & $\begin{array}{l}P \\
A \\
\%\end{array}$ & $\begin{array}{l}- \\
- \\
- \\
\end{array}$ & $\begin{array}{r}148 \\
114 \\
77 \% \\
\end{array}$ & $\begin{array}{c}2227 \\
36 \\
2 \% \\
\end{array}$ & $\begin{array}{c}234 \\
3 \\
1 \% \\
\end{array}$ & $\begin{array}{c}2609 \\
152 \\
6 \% \\
\end{array}$ & $\begin{array}{l}- \\
- \\
-\end{array}$ & $\begin{array}{l}- \\
- \\
-\end{array}$ & $\begin{array}{l}- \\
- \\
- \\
\end{array}$ & $\begin{array}{c}2609 \\
152 \\
6 \% \\
\end{array}$ \\
\hline 3 & $\begin{array}{l}P \\
A \\
\% \\
\end{array}$ & $\begin{array}{c}380 \\
13 \\
3 \% \\
\end{array}$ & $\begin{array}{c}176 \\
69 \\
39 \% \\
\end{array}$ & $\begin{array}{c}313 \\
5 \\
2 \% \\
\end{array}$ & $\begin{array}{c}95 \\
14 \\
15 \% \\
\end{array}$ & $\begin{array}{r}964 \\
101 \\
10 \% \\
\end{array}$ & $\begin{array}{c}1650 \\
633 \\
38 \% \\
\end{array}$ & $\begin{array}{c}385 \\
97 \\
25 \% \\
\end{array}$ & $\begin{array}{c}2035 \\
730 \\
36 \% \\
\end{array}$ & $\begin{array}{l}2999 \\
831 \\
28 \% \\
\end{array}$ \\
\hline 4 & $\begin{array}{l}\text { P } \\
\text { \% } \\
\end{array}$ & $\begin{array}{r}150 \\
3 \\
2 \% \\
\end{array}$ & $\begin{array}{r}350 \\
44 \\
13 \% \\
\end{array}$ & $\begin{array}{r}500 \\
107 \\
21 \% \\
\end{array}$ & $\begin{array}{l}- \\
- \\
\end{array}$ & $\begin{array}{c}1000 \\
154 \\
15 \% \\
\end{array}$ & $\begin{array}{l}700 \\
338 \\
48 \% \\
\end{array}$ & $\begin{array}{c}300 \\
18 \\
6 \% \\
\end{array}$ & $\begin{array}{c}1000 \\
356 \\
36 \% \\
\end{array}$ & $\begin{array}{c}2000 \\
510 \\
26 \% \\
\end{array}$ \\
\hline 5 & $\begin{array}{l}\mathrm{P} \\
\mathrm{A} \\
\% \\
\end{array}$ & $\begin{array}{r}39 \\
3 \\
8 \% \\
\end{array}$ & $\begin{array}{r}74 \\
43 \\
58 \% \\
\end{array}$ & $\begin{array}{c}255 \\
54 \\
21 \% \\
\end{array}$ & $\begin{array}{l}272 \\
209 \\
77 \% \\
\end{array}$ & $\begin{array}{l}640 \\
310 \\
48 \% \\
\end{array}$ & $\begin{array}{c}1197 \\
398 \\
33 \% \\
\end{array}$ & $\begin{array}{l}- \\
- \\
\end{array}$ & $\begin{array}{c}1197 \\
398 \\
33 \% \\
\end{array}$ & $\begin{array}{c}1837 \\
707 \\
38 \%\end{array}$ \\
\hline 6 & $\begin{array}{l}P \\
A \\
\%\end{array}$ & $\begin{array}{c}269 \\
- \\
- \\
\end{array}$ & $\begin{array}{c}146 \\
3 \\
2 \% \\
\end{array}$ & $\begin{array}{c}498 \\
3 \\
1 \% \\
\end{array}$ & $\begin{array}{c}672 \\
25 \\
4 \% \\
\end{array}$ & $\begin{array}{c}1585 \\
31 \\
2 \% \\
\end{array}$ & $\begin{array}{c}1655 \\
110 \\
7 \% \\
\end{array}$ & - & $\begin{array}{c}1655 \\
110 \\
7 \% \\
\end{array}$ & $\begin{array}{c}3240 \\
141 \\
4 \% \\
\end{array}$ \\
\hline 7 & $\begin{array}{l}\mathrm{P} \\
\mathrm{A} \\
\% \\
\end{array}$ & $\begin{array}{c}25 \\
4 \\
16 \% \\
\end{array}$ & $\begin{array}{c}22 \\
22 \\
100 \% \\
\end{array}$ & $\begin{array}{c}21 \\
21 \\
100 \% \\
\end{array}$ & $\begin{array}{c}23 \\
9 \\
39 \% \\
\end{array}$ & $\begin{array}{r}91 \\
56 \\
62 \% \\
\end{array}$ & $\begin{array}{r}59 \\
48 \\
81 \% \\
\end{array}$ & - & $\begin{array}{c}59 \\
48 \\
81 \% \\
\end{array}$ & $\begin{array}{l}150 \\
104 \\
69 \% \\
\end{array}$ \\
\hline 8 & $\begin{array}{l}P \\
A \\
\% \\
\end{array}$ & $\begin{array}{c}80 \\
12 \\
15 \% \\
\end{array}$ & $\begin{array}{c}122 \\
16 \\
13 \% \\
\end{array}$ & $\begin{array}{c}48 \\
39 \\
81 \% \\
\end{array}$ & $\begin{array}{c}204 \\
75 \\
37 \% \\
\end{array}$ & $\begin{array}{r}454 \\
142 \\
31 \% \\
\end{array}$ & $\begin{array}{l}495 \\
121 \\
24 \% \\
\end{array}$ & $\begin{array}{c}66 \\
34 \\
52 \% \\
\end{array}$ & $\begin{array}{l}561 \\
155 \\
28 \% \\
\end{array}$ & $\begin{array}{l}1172 \\
357 \\
30 \%\end{array}$ \\
\hline
\end{tabular}

- The disease appeared among heifers imported from USA 4 days after their arrived to the farm and 2 days. after their vaccination against FMD

$P$ : population of the animals.

A : Total number of affected animals.

$\%$ : Percentage of affected animals.

$M$ : Month. L.C. : lactating cows. $\quad$ D. \& I.C.H.: Dry and incalf heifers 